\title{
Shifts of Cohesion in Subtitling from English into Arabic: A Corpus-Based Study on Explicitation of Reference, Substitution, and Ellipsis
}

\author{
Halima Moud \\ Institute of Translation \\ University of Algiers 2, Algeria \\ Mohamed Salah Bekkouche \\ Institute of Translation \\ University of Algiers 2, Algeria
}

\begin{abstract}
Over the last decades, explicitation has been gaining ground in translation studies, especially after the formulation of Blum-Kulka's explicitation hypothesis in 1986. The present study aims to investigate explicitation in subtitling from English into Arabic by examining three cohesive devices i.e., reference, substitution, and ellipsis. For the purpose of this study, a parallel corpus was elaborated, consisting of fifteen TED-Ed lessons. The research material is one hour and four minutes, and the total word count of the parallel corpus is 17,491 words. The data collection and analysis were conducted manually. Instances of explicitation of cohesive devices were detected and categorized according to their nature i.e., reference, substitution, or ellipsis based on the model of cohesion proposed by Halliday and Hasan (1976). The findings of the study indicate that instances of explicitation of the three cohesive devices were observed in the corpus under investigation. The findings also show a high percentage of reference-based explicitation (75.86\%) followed by substitution-based explicitation (13.79\%) and ellipsis-based explicitation (10.34\%). Further investigation could be made to generalize the results using a larger corpus, exploring explicitation of other linguistic features, and including different genre of AVT products. Keywords: Cohesion, explicitation, parallel corpus, subtitling, subtitling constraints
\end{abstract}

Cite as: Moud, H., \& Bekkouche, M. S. (2020). Shifts of Cohesion in Subtitling from English into Arabic: A Corpus-Based Study on Explicitation of Reference, Substitution, and Ellipsis. Arab World English Journal for Translation \& Literary Studies 4 (3) 191-197.

DOI: http://dx.doi.org/10.24093/awejtls/vol3no3.15 
AWEJ for Translation \& Literary Studies Volume, 4 Number 3. August 2020

Shifts of Cohesion in Subtitling from English into Arabic

Moud \& Bekkouche

\section{Introduction}

Over the last decades, explicitation has been gaining ground in Translation studies. To better understand this phenomenon, researchers have become keenly interested in studying different aspects of explicitation, by investigating its universality (Blum-Kulka, 1986; Olohan \& Baker, 2000; Øverås, 1998), its surface manifestation in target text (TT) (Gumul, 2017/2006a; Pápai, 2004), the motivation behind it (Englund Dimitrova, 2005; Kamenická, 2008a; Weissbrod, 1992) using different types of corpora, both parallel and comparable corpora, in different modes of translation including written translation (Becher, 2011; Englund Dimitrova, 2005) interpreting (Gumul, 2017/2006a; Fang, 2018) and subtitling (Perego 2003) through various languages.

According to Englund Dimitrova (2005, p.33), "explicitation as a concept and term seems to have been first introduced by Vinay and Darbelnet" in their work about the comparative stylistics of French and English in 1958. The two scholars define explicitation as "a stylistic translation technique which consists of making explicit in the target language what remains implicit in the source language because it is apparent from either the context or the situation." (Vinay \& Darbelnet, 1958/1995, p. 342). Hence, explicitation usually implies the addition of extra words leading to an increased number of words in TT, making translations longer than source text (ST) regardless of the language-specific differences (Frankenberg-Garcia, 2004). This process can be problematic when it comes to some modes of translation known by their constraints. Subtitling is one of those modes of translation where the transfer of the message is constrained by several factors. Due to time and space restrictions, the displayed subtitles may be a condensed version of the original dialogue (Gottlieb, 2004). Therefore, the addition of extra information or explanations may not be favored.

Thus, the present paper aims at investigating explicitation in subtitling from English into Arabic by focusing on the rendition of three cohesion devices, namely reference, substitution, and ellipsis. The paper intends to address the question of whether or not reference, substitution, and ellipsis-based explicitation occur in subtitling from English into Arabic. If yes, what is the most frequent explicitation type?

\section{Literature Review}

Blum-Kulka (1986) has conducted what is often considered "the first systematic empirical study on explicitation." (Gumul, 2017, p. 21). Unlike Vinay and Darbelnet, Blum-Kulka limits her study to the increase of explicitness resulting from shifts of cohesion and coherence in TT. The scholar formulates the so-called "explicitation hypothesis", which postulates "an observed cohesive explicitness from SL to TL texts regardless of the increase traceable to differences between the two linguistic and textual systems involved." (Blum-Kulka, 1986, p. 292).

Fang (2018) has investigated the characteristics of explicitation in consecutive interpreting between Chinese and English among professional and student interpreters. The results of her study reveal that about $30 \%$ of the detected instances of explicitation are cohesion-related. Cohesionrelated explicitation falls under the category of textual explicitation, which is achieved through

Arab World English Journal for Translation \& Literary Studies 
AWEJ for Translation \& Literary Studies Volume, 4 Number 3. August 2020

Shifts of Cohesion in Subtitling from English into Arabic

Moud \& Bekkouche

three kinds of explicitation, namely reference-based explicitation, ellipsis-based explicitation, and conjunction-based explicitation.

Gumul (2017) has examined different aspects of explicitation in simultaneous interpreting between Polish and English among trainee interpreters. The results of her study indicate "the dominance of cohesive explicitness ..., which accounts for over $70 \%$ of all shifts detected in the analysed interpreting outputs." (Gumul, 2017, p. 146). This covers a large variety of explicitation shifts, including adding connectives, reiterating lexical items, shifts from reiteration in the form of paraphrase to reiteration in the form of identical/partial repetition, shifts from referential cohesion to lexical cohesion (i.e., lexicalization of pro-forms), filling out elliptical constructions, and categorical shifts of conjunctive cohesive devices (i.e., from vaguely cohesive to more explicitly cohesive).

In Arabic studies, a study conducted by Algryani (2020) about explicitation in the translation of noun phrase ellipsis from English into Arabic suggests that there is a tendency towards explicitation in TT by filling out elliptical structures through lexical repetition. This tendency can be attributed to "structural incompatibilities and differences in stylistic preferences between English and Arabic." (Algryani, 2020, p. 35).

Izwaini \& Al-Omar (2019) were interested in studying shifts of cohesion in subtitling by investigating the translation of substitution and ellipsis in Arabic subtitling. Their research findings have demonstrated that the majority of substitution and ellipsis instances detected in ST where explicitated in TT. The statistics show that $63.15 \%$ of substitution instances and $35.3 \%$ of ellipsis instances where rendered by translators using lexical repetition making a shift from grammatical cohesion in ST to lexical cohesion in TT. The two researchers have also noted that "although some cases would be cohesive in Arabic using ellipsis or substitution, translators used repetition instead." (Izwaini \& Al-Omar, 2019, p.149).

Another study, proposed by El-Nashar (2016), has analysed explicitation techniques used in the translation of official institutional texts between English and Arabic. The findings of his study indicate that a variety of explicitation shifts was detected in TT, including reference-based explicitation (22.85\%), substitution-based explicitation (1.63\%), and ellipsis-based explicitation $(0.72 \%)$.

\section{Methodology}

The research material used in the present paper comprised a parallel corpus consisting of fifteen TED-Ed lessons. The texts were selected according to their content as they deal with the human body and its overall health. They were collected from the Amara website, a dedicated online platform for subtitling used to translate TED-Ed video lessons. The total time duration of the audiovisual materials is one hour and four minutes. The total word count of the parallel corpus is 17,491 words comprising 9,183 words for the English sub-corpus and 8,308 words for the Arabic sub-corpus.

Arab World English Journal for Translation \& Literary Studies 
The data collection and analysis were conducted manually. Instances of explicitation of the three cohesive devices were detected and collected. Later, they were categorized according to their nature i.e., reference, substitution, or ellipsis. For this purpose, Halliday and Hasan's model on cohesion (1976) made the theoretical framework for the present study.

\section{Results and Discussions}

The present paper aims to investigate cases of explicitation of three cohesive devices i.e., reference, substitution, and ellipsis in subtitling from English into Arabic. The analysis of the corpus under investigation has revealed instances of cohesion-related explicitation in TT. The results obtained from the data analysis are presented in the following table:

Table 1. A summary of occurrences and percentage of reference, substitution, and ellipsis-based explicitation

\begin{tabular}{lllll}
\hline & Reference & Substitution & Ellipsis & Total \\
\hline Occurrence & 22 & 4 & 3 & 29 \\
\hline Percentage & $75.86 \%$ & $13.79 \%$ & $10.34 \%$ & $99.99 \%$ \\
\hline
\end{tabular}

As table 1. indicates, instances of explicitation where observed in terms of all three cohesive devices i.e., reference, substitution, and ellipsis in the corpus under investigation. The total occurrences of explicitation found in the corpus are 29 occurrences. The data analysis indicates a significant amount of reference-based explicitation (22 occurrences) comparing to substitution-based explicitation (4 occurrences) and ellipsis-based explicitation (3 occurrences). Consequently, reference-based explicitation was applied with the highest percentage (75.86\%) in TT in comparison with substitution-based explicitation (13.79\%) and ellipsis-based explicitation $(10.34 \%)$.

In the following section, we will discuss some examples of explicitation extracted from the parallel corpus under investigation.

Example 1: reference-based explicitation

Example (1) illustrates a case of explicitation of a personal reference using the personal pronoun "they". The example is as follows:

(ST): At that point, they can transform into colon cancer.

(TT): عند هذه المرحلة، يمكن أن تتحول هذه الزوائد إلى سرطان القولون

Example (1) illustrates an instance of an anaphoric reference. The personal pronoun "they" refers back to another item mentioned earlier in the text, which is "the polyps". When rendered into Arabic, the referent was made explicit in TT. The translator made an explicitation of the reference relation by translating the personal pronoun "they" by its referent "الزوائد" (the polyps), so the reader does not need to go back into the text to identify which item the personal pronoun "they" is referring back to.

Example 2: substitution-based explicitation

Arab World English Journal for Translation \& Literary Studies

ISSN: 2550-1542 | www.awej-tls.org 
AWEJ for Translation \& Literary Studies Volume, 4 Number 3. August 2020

Shifts of Cohesion in Subtitling from English into Arabic

Moud \& Bekkouche

Example (2) illustrates a case of explicitation of a nominal substitution where a noun is replaced by "ones". The example is as follows:

(ST): Different ones respond to different types of damage.

(TT): حيث يستجيب كل أنزيم لنوع معين من الضرر

In example (2), the substitute "ones" replaces in ST another noun in the text, which is "enzymes". The sentence would be "Different enzymes respond to different types of damage"; however, lexical repetition was avoided in ST. The Arabic rendition of ST indicates a case of explicitation where the substitute "ones" was rendered by the word "أنزيج" (enzyme). The translator opted for the explicitation of the substitution relation by translating the substitute "ones" in ST by the substituted noun "أنزيم" in TT, so the reader can easily identify the substituted noun without going back into the text.

Example 3: ellipsis-based explicitation

Example (3) illustrates a case of explicitation of a nominal ellipsis with the non-specific deictic "each". The example is as follows:

(ST): ويحتوي كل فص على خلايا أصغر تسمى جُرَيبات

(TT): that each contains smaller cells called follicles,

In example (3), the non-specific deictic "each" was elliptically used in the ST to avoid lexical redundancy. The full structure of the elliptical expression would be "each lobule"; however, the word "lobule" was left out in ST since the meaning could be inferred from the text. The elliptical structure was rendered into Arabic by filling out the omitted part of the sentence in TT, so the word "فص" (lobule) was added in the sentence.

The findings of this research paper relate quite significantly to the literature in the field. The presence of explicitation in subtitling in general, and in subtitling from English into Arabic in particular, was evidenced, at least at the cohesion level. The translators performed explicitation of cohesive devices i.e., reference, substitution, and ellipsis even when it was possible to maintain the same category of the cohesive device in TT, making a categorical shift from grammatical cohesion into lexical cohesion. However, it is not possible to assume that the tendency towards explicitation was observed in the majority cases when rendering the cohesive devices into Arabic since our study aimed only to highlight cases of explicitation in the translation of reference, substitution, and ellipsis from English into Arabic.

\section{Conclusion}

The present study has investigated the concept of explicitation in subtitling from English into Arabic by examining three cohesive devices i.e., reference, substitution, and ellipsis. The results of the data analysis have revealed that instances of explicitation were detected with all three cohesive devices in the corpus under investigation. The study has also shown that reference has observed the highest percentage of explicitation cases (75.86\%) followed by substitution (13.79\%) and ellipsis $(10.34 \%)$. The findings of this study can broaden the current understanding of subtitling process and the different procedures involved during the process of message transfer.

Arab World English Journal for Translation \& Literary Studies 
AWEJ for Translation \& Literary Studies Volume, 4 Number 3. August 2020

Shifts of Cohesion in Subtitling from English into Arabic

Moud \& Bekkouche

Further investigation could be made to generalize the results using a larger corpus, examining explicitation of other linguistic features, and including different genres of AVT products.

\section{About the Authors:}

Halima Moud is a PhD student at the Institute of translation at the University of Algiers 2. Her areas of interest include translation studies, audiovisual translation, and corpus-based studies.

ORCID ID: https://orcid.org/0000-0001-8570-2690

Mohamed Salah Bekkouche is a professor at the University of Algiers 2, and the head of the laboratory of translation of historical documents at the same university. He has been supervising both undergraduate and postgraduate students since 1990. He is in charge of $\mathrm{PhD}$ project programme on Translation of science and technology. He is also training PhD students at the Institute of translation, the Department of English studies, and the Department Spanish studies. ORCID ID: https://orcid.org/0000-0001-2345-6789

\section{References}

Algryani, A. (2020). Remarks on the Translation of Noun Phrase Ellipsis from English into Arabic. Arab World English Journal for Translation \& Literary Studies, 4, (1), 124-36. DOI: http://dx.doi.org/10.24093/awejtls/vol4no1.3

Becher, V. (2011). Explicitation and Implicitation in Translation. A Corpus-Based Study of English-German and German-English Translations of Business Texts. Doctoral dissertation. Hamburg: University of Hamburg.

Blum-Kulka, S. (1986). Shifts of cohesion and coherence in translation. In House, J., \& BlumKulka, S. (eds.), Interlingual and Intercultural Communication: Discourse and Cognition in Translation and Second Language Acquisition Studies, 17-35. Tübingen: Gunter Narr.

El-Nashar, M. M.M. (2016). Explicitation techniques in English-Arabic translation: A linguistic corpus-based study. Arab World English Journal, 7, (3), 317-335. DOI: $10.24093 /$ awej/vol7no3.23

Englund Dimitrova, B. (2005). Expertise and Explicitation in the Translation Process. Amsterdam/Philadelphia: John Benjamins.

Fang, T. (2018). Explicitation in consecutive interpreting. Amsterdam/Philadelphia: John Benjamins.

Frankenberg-Garcia, A. (2004). Are translations longer than source texts? A corpus-based study of explicitation. Paper presented at Third International CULT (Corpus Use and Learning to Translate) Conference, Barcelona, 22-24. January 2004.

Gumul, E. (2006a). Explicitation in simultaneous interpreting: A strategy or a by-product of language mediation?. Across Languages and Cultures. A Multidisciplinary Journal for Translation and Interpreting Studies, 7, (2), 171-190. DOI: 10.1556/Acr.7.2006.2.2

Gumul, E. (2017). Explicitation in simultaneous interpreting: a study into explicitating behaviour of trainee interpreters. Katowice : Wydawnictwo Uniwersytetu Śląskiego

Gottlieb, H. (2004). Subtitles and International Anglification. Nordic Journal of English Studies, 3, (1), 219-230. DOI: https://doi.org/10.35360/njes.32

Halliday, M.A.K., \& Hasan, R. (1976). Cohesion in English. London/New York: Longman.

Arab World English Journal for Translation \& Literary Studies 
Izwaini, S., \& Al-Omar, H. (2019). The translation of substitution and ellipsis in Arabic subtitling. Journal of Audiovisual Translation, 2, (1), 126-151.

Kamenická, R. (2008a). Explicitation profile and translator style. In Pym, A. \& Perekrestenko, A. (eds.), Translation Research Projects 1, 117-130. Tarragona: Universidad Rovira i Virgili.

Olohan, M., \& Baker, M. (2000). Reporting that in translated English. Evidence for subconscious processes of explicitation?. Across Languages and Cultures. A Multidisciplinary Journal for Translation and Interpreting Studies, 1, (2), 141-158. DOI: https://doi.org/10.1556/Acr.1.2000.2.1

Øverås, L. (1998). In search of the Third Code: An investigation of norms in literary translation. Meta, 43, (4), 571-588. DOI: https://doi.org/10.7202/003775ar

Pápai, V. (2004). Explicitation: A universal of translated texts? In Mauranen, A., \& Kujamaki, P. (eds.), Translation Universals: Do They Exist?. 143-164. Amsterdam/Philadelphia: John Benjamins.

Perego, E. (2003). Evidence of explicitation in subtitling: Towards a categorisation. Across Languages and Cultures. A Multidisciplinary Journal for Translation and Interpreting Studies, 4, (1), 63-88. DOI: 10.1556/Acr.4.2003.1.4

Vinay, J.P., \& Darbelnet, J. (1958/1995). Comparative Stylistics of French and English: A Methodology for Translation. Amsterdam/Philadelphia: John Benjamins.

Weissbrod, R. (1992). Explicitation in translation of prose-fiction from English to Hebrew as a function of norms. Multilingua, 11, (2), 153-171.

Arab World English Journal for Translation \& Literary Studies 